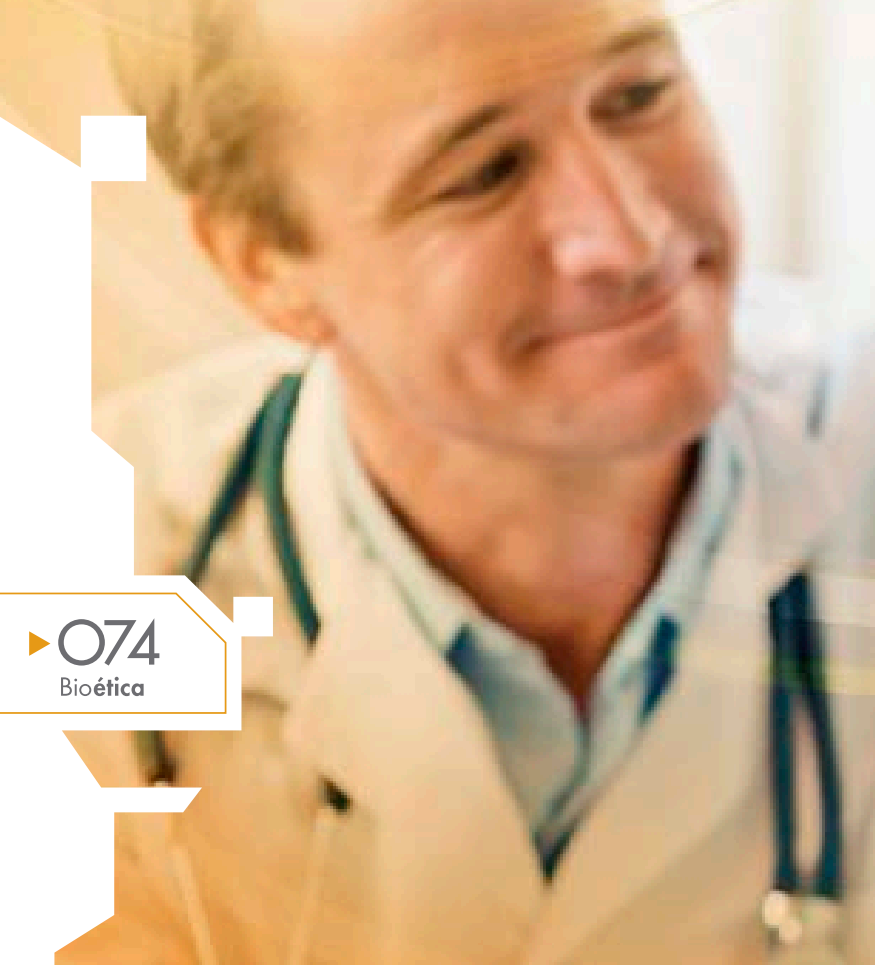

$>$ Dario Palhares*

$>$ Antônio Carlos Rodrigues da Cunha**
ENFOQUE ÉTICO DE SITUACIONES DE AGRESIÓN QUE INVOLUCRAN A PACIENTES DEPENDIENTES Y A MIEDICOS
ABORDAGEM ÉTICA PARA SITUAÇÖES DE AGRESSÃO QUE ENVOLVAIVI PACIENTES DEPENDENTES E MÉDICOS

\title{
Ethical approach to aggressive situations involving dependent
} patients and doctors 


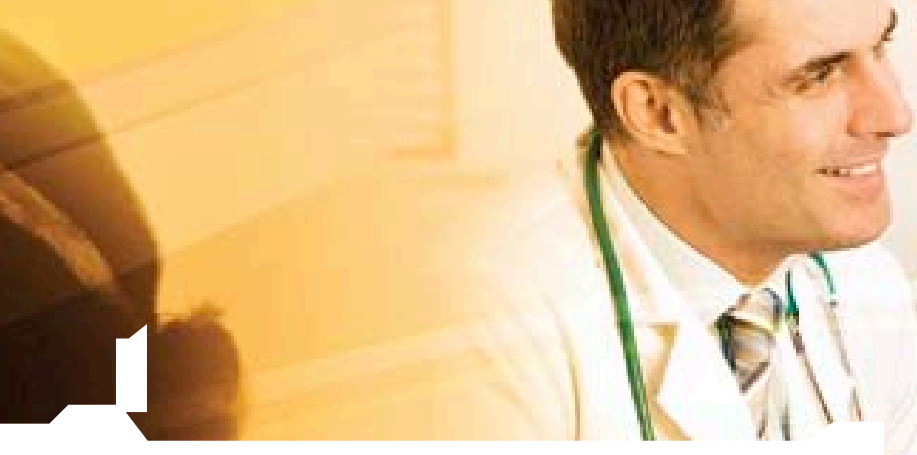

ACKNOWLEDGEMENTS

We would like to thank Content Concepts for the English review and correction and Leandro Brambilla Martorell for the comments on the text.

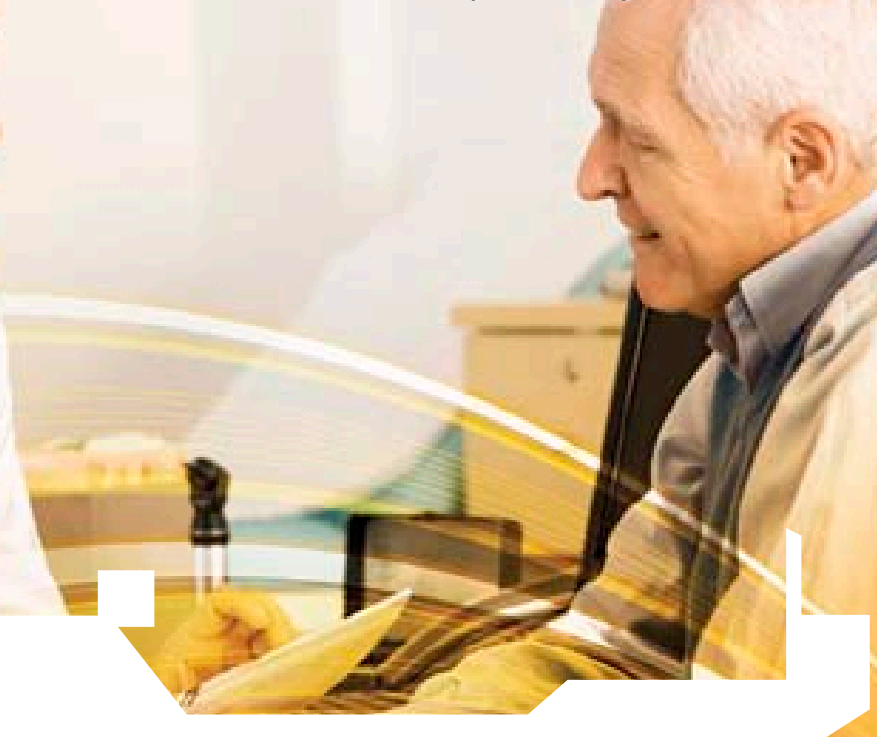

\section{RESUMEN}

Con frecuencia los trabajadores del sector de asistencia en salud afrontan el comportamiento agresivo de los pacientes. Cuando está involucrado un paciente dependiente, la situación se vuelve más compleja ya que este es el más débil y no es responsable del acto agresivo. El niño que es llevado al médico, probablemente esté enfermo. Sin embargo, si un adulto entra en conflicto con un profesional serán menores las posibilidades de una línea de tratamiento clara y promisoria. Sin embargo, en tal caso el niño debe ser examinado y, si hubiese señales clínicas de alerta, el niño debe ser atendido y tratado de inmediato; de lo contrario, será remitido a otro profesional.

\section{Palabras Clave}

Alcoholismo, discapacidad, violencia, doctor, enfermera.

\section{SUMMARY}

Workers in the Health Assistance sector frequently face aggressive behavior from patients. When a dependant patient is involved, the situation gets more complex, since he or she is the weakest link and is not responsible for the aggressive act. The child who is taken to the doctor is probably sick. However, if an adult gets into a conflict situation with a professional, chances of a clear and hopeful line of treatment will be less. In such cases, the child must at least be examined. If alert clinical signs are present, the child must be immediately treated, otherwise he/she must be referred to another professional.

\section{Keywords}

Alcoholism, incapacity, violence, doctor, nurse.

\section{RESUMO}

Os trabalhadores do setor de assistência em saúde muitas vezes enfrentam o comportamento agressivo dos pa $\neg$ cientes. Quando um paciente dependente está envolvido, a situação se torna mais complexa uma vez que este é o mais fraco e não é responsável pelo ato agressivo. A criança que é levada para o médico é provavelmente doente. No entanto, se um adulto entra em conflito com um profissional, as possibilidades de uma linha clara e esperançosa de tratamento será menor. Nesses casos, a criança deve, no entanto, ser examinado. examinado. Se houver sinais clínicos de alerta, a criança deve ser tratada imediatamente; caso contrário, será referido à outro profissional.

\section{Palavras-Chave}

Alcoolismo, deficiência, violência, médico, enfermeira. 


\section{INTRODUCTION}

In the majority of cases, the doctor-patient relationship is strongly based on mutual respect and is smooth and satisfactory to both. However, due to the large number of patients that the health professionals have to take care of, the latter paradoxically become victims of aggression meted out by some patients.

Aggression towards the professionals is an event deviating from the norm, the essence and the finality of the doctor-patient relationship. Regrettably, this kind of occurrence has become more and more frequent. This is a serious problem facing the departments of public health and labor medicine: in different countries such as Sweden, Spain, Great Britain, Canada and even in rural areas of India, this problem has arisen with many aspects in common.

In an aggressive situation, the work of the professional is severely damaged and can result in the rupture of the patient-professional relationship. These situations are previewed in the deontological codes and in the general legal codes of the societies.

But there is a particularly delicate situation that emerges when dependent patients (often children, but also other patients who are dependent) are involved. Here, the person who attacks the professional is not the patient, but his/her caretaker. If an attack on a professional is a complex situation, the aggression by a person responsible for the patient is even more complex, as it involves not two people but three, where the patient is totally vulnerable, both because of his/her incapacity and dependency but also for being subjected to an injustice, as it is not the patient who exhibits the aggressive behavior.

In this way, the present text proposes a bioethical debate about the question of violence against health professionals, with the objective to propose protection measures for those patients who are pulled into an aggressive event involving the custodians of dependent patients.

\section{VIOLENCE}

The phenomenon of violence needs to be understood in the context of the interface between biological life and social construction.

Biologically, aggressiveness is inherent to humans. The aggressive pulse, when well channelized, is a very important tool to survive and for self defense. However, uncontrolled violent episodes are socially modifiable; hence they must be questioned and studied. The violent acts must be studied, questioned and handled in relation to psychological and neurophysiologic aspects and in relation to social and cultural aspects.

Socially speaking, violence is a set of practices that aim to dominate and subjugate. A violent act naturally creates two opposite poles. Violence is to act with no arguments, no speech. Violence is basically action without any justification; it is purely and simply a desire to dominate.

Violence acts briefly and intensely occur in a determined place and time. Violent acts can sometimes destabilize societies and estates, but never pure and simple violence creates mechanism of plentiful power- power understood in its two definitions: the one of power-to-construct and the one of repression. Violence is in fact more identified as a reaction to the weakness of the social power: it is stronger and more frequent in places characterized by an inept State. As John Gray points out, civil freedom is a point between tyranny and anarchy. So, in places where violence dominates, everything goes silent: people, law, victims.

This paper seeks to analyze the consequences of violence in the patient-doctor context, both vis-a-vis public policies and laws to prevent it, opening spaces for the construction of ethical mechanisms capable of neutralizing violence and respecting and protecting the vulnerable and dependent. Thus, it is not a question of only describing sublime and abstract ethical principles, it is needed to discuss and develop ethical mechanisms of intervention facing the social phenomenon of violence.

If violence is a deep psychological aspect of humans, it will be evident even in the spheres of healthcare: clinics, hospitals, offices, etc. From a purely neurophysiologic perspective, humans show a greater tendency of aggressiveness in situations of suffering. Therefore it is not surprising the occurrence of those arenas of healthcare, which support people undergoing intense suffering are prone to manifestations of aggression.

\section{VIOLENCE AGAINST HEALTHCARE PROFESSIONALS}

As a consequence of the exponential scientific development in the field of medical practice, the doctor-patient relationship has changed deeply and quickly in this last Century. When medical technology was experiencing scarce resources, assistance was basically palliative care and the doctor had a paternal aura. Once medical assistance is backed by efficient therapeutic resources, 
the doctor is seen as a person with whom a contract of services has been signed; a contract that must be characterized by excellence, scientific update, open information to the patient and respect for his autonomy.

The institutionalization and the wide scope of health services allowed that a larger number of people could now have access to health technology. However, the downside is that it led to a depersonalization of assistance to the patient. Especially in first aid care, but also in other units, the patients could not choose the professional who would take care of them, but only an institution where they could be referred to any doctor. Moreover, the doctor could be different during every visit to the hospital and the patients could be confronted with new names and new faces. The situation can even be more stressful since each professional presents different practices, which can confound the patient.

As a consequence of this new organization within the health services, the professional is being paid not by the quality and precision of the care that he/she provides but by the number of patients that he/she attends to. This gives rise to an impersonal relationship between the patient and the doctor. It becomes a purely administrative, bureaucratic relationship even though it involves the health, privacy, integrity, individuality, in fact the life of the patient. The health of the patient is in the hands of a health provider who is chronically tired and stressed.

Clearly, it is the coldness and aloofness of the doctorpatient relationships in institutional settings that forms the background for both the increase in claims and the increase in aggressive behavior against health care providers. In other words, the professionals also end up as victims of a complex system that damages both the doctor and patient. As expected, the most critical arenas are those which witness an aggressive manifestation of some patients: first-aid services, psychiatric inpatients and geriatric services.

We can borrow from physics the metaphor that 'attrition is the force that appears when two or more bodies are in contact' to clarify that human relationships involve some kind of erosion. The intention is not to eliminate attrition, but rather to know how to ethically work with this aspect of life that includes the doctor-patient relationship. Obviously, there is a nebulous, imprecise, indefinite limit after which attrition turns into aggression, invalidating any medical procedure on the patient.

One of the manifestations of interpersonal attrition is the claim demanded from services. In the current cultural context, medical assistance is not viewed as a favor or mercy, but a right to be guaranteed by the State; where the doctor-patient relationship is a service contract. Here, the most obvious and expected consequence is the increase in the number of claims against medical services. Such increase is not reflective of the inherent attrition to all human relationships. Since the paternalistic era of the nineteenth Century, the medical teachers have emphasized the importance of the medical records as a way of defense against 'the whims of certain patients'. Anyway, Winstanley \& Wellington (2004) point out that in the UK the register of aggressiveness towards health care professionals increased from 1998 to 2001, but they question if there was a real increase of aggressive episodes or if there was merely a more detailed report.

The first psychological reaction of humans facing criticism or claims is one of emotional self-defense: the negative feedback hits and shakes the emotional side of health professionals. However, claims must be rationally analyzed as a means of self-improvement of the professional. In medium and long term, patients who explicitly claim are preferable to those who are silent and don't search for a determined service anymore. Indeed, claims, especially when relevant and well founded, allow the improvement of the staff and the services, while those who are silent don't add anything.

Definitely, the staff must give an open hearing to the claims. But they do not have to accept aggression. The right of not being assaulted is presented in law. However, in reality, what constitutes protest and what constitutes contempt is not defined. In Brazil, the $33^{\text {rd }}$ Article of the Code of Medical Ethics prohibits the doctor 'to not attend patients who seek their professional services in cases where there is no other doctor or medical services in conditions to do it' and the first paragraph of the $36^{\text {th }}$ Article states that 'occurring facts that at their discretion affect the proper relationship with the patient or affect the full professional performance, the doctors have the right to cancel the service (...) assuring that other professional will continue the assistance'.

One can understand this deontological code by reading what is not written. A paradigmatic analysis shows that the patient has the right of assaulting or being angry at the health professional. This translates into the patient's right of being assisted in spite of his behavior or a soured doctor-patient relationship. If the doctor is obliged at any cost to attend patients in situations of urgency 
or emergency, the patient can provoke the health professional, for example, if they are under psychoactive substances (alcohol, drugs); or under acute psychiatric crisis; or under imminent risk of life and, mainly, if there is no other doctor to give assistance to that particular patient.

Also, the paradigm is that the distinction between claim and aggression is not clear, so that the doctor can interrupt the treatment, since the care of the patient is continued by another professional.

So, the epidemiologic fight regarding the topic of aggression against health professionals is not clear or explicit in the deontological codes. Although the construction of a good doctor-patient relationship is essential for harmonious work environment, it is not enough to count only on it to provide protection to the care giver. The whole context of humanization of the health service, with practices of host, query before the consult, adequate dimension of the service regarding demand (physical space, number of professionals on duty, etc.) is a prophylactic of aggression against professionals. And, as in any other place where there is a large influx of persons; structures of safety must be in place to promptly intercede when necessary.

The symbolic substrate of aggression against healthcare providers presents an anthropologically cyclic behavior, as evidenced by ethnographic studies about the South American shamans. The shaman, primordium of the medical profession, appears as a person capable of communicating with the Beyond, with the spirits. The shaman is revered due to his divine and beneficial powers. However, as he speaks to the forces of the Beyond, he may become threatening. An illustrative situation occurred in a tribe when the shaman went to examine a dying person. He brought the message that he would die within three days. However, the dying person had survived for more than five days. The authority of the shaman was so great that the tribe decided to kill the person so that the shaman would not lose his power to speak to the spirits. At that moment, the shaman proved that not only did he have the power to talk to the spirits but also that, in a hypothetical situation he could determine the tribe to execute a healthy member, if the spirits brought a bad message at any time. The situation ended when somebody killed him with the silent support of the tribe as a whole. For a long period the tribe was without the protection of a shaman, until a new member started to present the ability to communicate with the spirits...
This ethnographic study is important to understand the cyclic phases of Medicine. In the beginning, the health of people was in danger. Then, Medicine stepped in, symbolically speaking, to the spirits (even the scientific knowledge about human diseases uses a considerably hermetic language) and alleviated the suffering of people. Slowly the doctors gained a symbolic power of life and death over the society. At that moment they appeared threatening and controlling; it started their symbolic demise, until society again realized the importance of medicine.

Medicine undergoes social moments when it is akin to salvation and others when it is damned. According to the anthropological approach, the profession of doctors can be extremely venerated or summarily judged. For example, there are countries where even grossly unethical doctors keep working and other countries where doctors are meted out severe civil punishments even when no ethical mistakes have been made by them. Social practices oscillate in their paradigmatic approach regarding violent behavior against health professionals: Are the doctors safe in their work place? Or are they exposed and exploited in a system where their numbers cannot match the social demand?

Besides this anthropological question, sometimes the figure of the health services is merely the one of an attenuator of social tensions. Public policies are sometimes so distorted that they increase the number of people living in inhumane conditions. The situation is so warped that for the time they are meeting with the doctor it appears that humanity is preserved, even though just a few minutes later they are back to their original state of living without water, proper sewage facilities, provision to go to school, stable employment, etc. Also, it is not important that the health place doesn't have the technology that science created. It is only important that the doctor-patient relationship is as aseptic as possible. If someone is to protest, it is better to protest inside and against the health service than in the government arena.

\section{THE MINOR AND THE DEPENDENT}

When a health care professional works with a pediatric patient or with a dependent, it is not a dyad anymore, but a triad. The patient is an innocent figure who is totally dependent on someone responsible for his/her maintenance. The condition of the pediatric or the dependent patient is such that there is no scope of any type of aggressive 
manifestation, in the legal definition. But what if the person responsible for this patient assaults the health professional? And what happens if it occurs in a first aid service, where the chance that the patient needs emergency care is high?

The pediatric or dependent patient depends on his/ her custodian not only from the legal point of view, but also from the practical point of view. The warden will provide the doctor with the clinical history of the patient and there is no medical prescription to follow.

In daily situations, the legal caretaker takes the decisions about the treatment of his ward. The responsible adult is the holder and the representative of the patient. However, this situation is not absolute: a decision from the medical staff is imperative in clinical situations where there is an immediate and significant risk to the patient. A common example is a newborn who develops malignant jaundice and needs phototherapy. Due to the risk of kernicterus, the child is not admitted and the parents refuse phototherapy or blood transfusion.
Thus, the patient must be protected from the aggressive behavior of his caretaker. The first consequence of aggression shown by the caretaker is that the most important element of clinical practice - the clinical history - is lost. Even if the caretaker answers questions fielded by the doctor, the reliability and the precision of the information is unconvincing.

The doctor may try to obtain information directly from the patient (if he or she is able to provide it) and from a physical exam. If signs of imminent risk or obvious suffering are present, the patient must be admitted and treated in the institution.

However, if clear signs of immediate severity are absent, the doctor should not prescribe any medicine as the doctor-patient relationship is irretrievably broken hence there is no safety or confidence that the prescription will be correctly followed. The patient and his/her caretaker should be referred to some other doctor. Or, another adult may be asked to take responsibility for the patient.

\section{REFERENCES}

SAMPAIO, A. C.; SILVA, M. R. F. (2010). Medical records: reflex of physician-patient relationship. Bioética 18 (2), pp. 451-468.

- BARON, R. A.; NEUMAN, J. H. (1996). Workplace violence and workplace aggression: evidence of their relative frequency and potential causes. Aggressive Behavior 22, pp. 161-173.

- ARNETZ, J.E.; ARNETZ, B.B.; PETTERSON, I. L. (1996). Violence in the nursing profession: occupational and lifestyle risk factors in Swedish nurses. Work and Stress 10, pp. 119-127.

- LEÓN, M. M. (2010). The emerging risk that constitutes aggressions and violence that physicians suffer performing their profession: the case of Spain. Bioética, 18 (2), pp. 263-274.

- WINSTANLEY, S.; WHITTINGTON, R. (2004). Aggression towards health care staff in a UK general hospital: variation among professionals and departments. Journal of Clinical Nursing 13, pp. 3-10.

- RIPPON, T. J. (2000). Aggression and violence in health care professions. Journal of Advanced Nursing; 31 (2), pp. 452-460.

- BAWASKAR, H. S.; BAWASKAR, P. (2012). Problems of isolated private hospitals in a rural setting. Indian Journal of Medical Ethics 9 (4), pp. 289-290.

- SOUZA, P. V. S. (2006). O médico e o dever legal de cuidar: algumas considerações jurídico-penais. Bioética, 14 (2), pp. 229-238.

- ARENDT, H. (1970). On Violence. New York: Harvest Books.

- BUSS, A. H. (1961). The Psychology of Aggression. New York: John Wiley \& Sons.

- DINIZ, D.; GUILHEM, D. (2005). O que é Bioética. São Paulo: Brasiliense.

- GRAY, J. (2002). Straw Dogs. New York: Farrar, Straus and Giroux.

- PALHARES, D.; SANTOS, I. L. (2012). Pre-employment medical testing in Brazil: ethical challenges. Indian Journal of Medical Ethics 9 (4), pp. 266-268.
RODRIGUES, C. F. A. (2010). Ethical considerations about contemporary medicine: a punctual reflection. Bioética, 18 (2), pp. 373-379.

- MURR, L. P. (2010). The onus probandi inversion in characterizing medical error by the Brazilian Law. Bioética, 18 (1), pp. 31-47.

- TANDON, S. (2013). Of poor patients and callous doctors. Indian Journal of Medical Ethics, 10 (1), p. 68.

- ENGELHARDT, H. T. (2009). Ética médica: códigos de ética médica e bioética. Bioética, 17 (3), pp. 355-362.

- FORTES, P. A. C. (2004). As condições de vida, de trabalho e de saúde como caldo de cultura para a violência. Bioética, 12 (2), pp. 113-119.

- MEnezes, R. A. (2004). Em Busca da Boa Morte: Antropologia dos Cuidados Paliativos. Rio de Janeiro: Fiocruz.

- RIBEIRO, D. (1996). Diários Índios. São Paulo: Companhia das Letras.

- GarrafA, V. (2006). Bases Conceituais da Bioética - Enfoque Latino-Americano. São Paulo: Global.

- GARRAFA, V.; PYRRHO, M. (2008). Bases epistemológicas e políticas da bioética de intervenção. In: Moysés, S. T., Kriger, L., Moysés, S. J. (orgs). Saúde bucal das famílias: trabalhando com evidências. São Paulo: Artes Médicas, pp. 298-308.

- PONTES, C. A. A.; SCHRAMM, F. R. (2004). Bioética da proteção e papel do Estado: problemas morais no acesso desigual à água potável. Cadernos de Saúde Pública, 20 (5), pp. 1319-1327.

- TAQuetTe, S.; VILHENA, M. M.; SilVA, M. M.; VATE, M. P. (2005). Conflitos éticos no atendimento à saúde de adolescentes. Cadernos de Saúde Pública, 21, pp. 1717-1725.

- RYAN, J.; POSTER, E. C. (1991). When a patient hits you: a post-assault program that put nurses first. Canadian Nurse, 87, pp. 23-25. 